\title{
Effect of Magnesium Addition and High Energy Processing on the Degradation Behavior of Iron Powder in Modified Hanks' Solution for Bioabsorbable Implant Applications
}

\author{
Rafael G. Estrada ${ }^{1,2} \mathbb{D}$, Marta Multigner ${ }^{2}$, Marcela Lieblich ${ }^{1, * \mathbb{D}}$, Santiago Fajardo ${ }^{1}$ and Joaquín Rams $^{2} \mathbb{D}$ \\ 1 Centro Nacional de Investigaciones Metalúrgicas (CENIM-CSIC), 28040 Madrid, Spain; \\ rafaelem@cenim.csic.es (R.G.E.); fajardo@cenim.csic.es (S.F.) \\ 2 Department of Applied Mathematics, Materials Science and Engineering and Electronic Technology, \\ Universidad Rey Juan Carlos (URJC), 28933 Madrid, Spain; marta.multigner@urjc.es (M.M.); \\ joaquin.rams@urjc.es (J.R.) \\ * Correspondence: marcela@cenim.csic.es
}

Citation: Estrada, R.G.; Multigner, M.; Lieblich, M.; Fajardo, S.; Rams, J. Effect of Magnesium Addition and High Energy Processing on the Degradation Behavior of Iron Powder in Modified Hanks' Solution for Bioabsorbable Implant Applications. Metals 2022, 12, 78. https://doi.org/ $10.3390 / \operatorname{met} 12010078$

Academic Editors: Changdong Gu, Leszek Adam Dobrzanski and Sandra Carolina Cifuentes Cuéllar

Received: 29 November 2021 Accepted: 27 December 2021 Published: 4 January 2022

Publisher's Note: MDPI stays neutral with regard to jurisdictional claims in published maps and institutional affiliations.

Copyright: (c) 2022 by the authors. Licensee MDPI, Basel, Switzerland. This article is an open access article distributed under the terms and conditions of the Creative Commons Attribution (CC BY) license (https:// creativecommons.org/licenses/by/ $4.0 /)$.

\begin{abstract}
This paper shows the results of applying a combination of high energy processing and magnesium $(\mathrm{Mg})$ as an alloying element in a strategy for enhancing the degradation rate of iron $(\mathrm{Fe})$ for applications in the field of non-permanent medical implants. For this purpose, Fe powder was milled with $5 \mathrm{wt} \%$ of $\mathrm{Mg}(\mathrm{Fe} 5 \mathrm{Mg})$ and its microstructure and characterized degradation behavior. As-received Fe powder was also milled in order to distinguish between the effects due to high energy processing from those due to the presence of $\mathrm{Mg}$. The powders were prepared by high energy planetary ball milling for $16 \mathrm{~h}$. The results show that the initial crystallite size diminishes from $>150 \mathrm{~nm}$ to $16 \mathrm{~nm}$ for Fe and $46 \mathrm{~nm}$ for Fe5Mg. Static degradation tests of loose powder particles were performed in Hanks' solution. Visual inspection of the immersed powders and the X-ray diffraction (XRD) phase quantification indicate that Fe5Mg exhibited the highest degradation rate followed by milled $\mathrm{Fe}$ and as received $\mathrm{Fe}$, in this order. The analysis of degradation products of Fe5Mg showed that they consist on magnesium ferrite and pyroaurite, which are known to present good biocompatibility and low toxicity. Differences in structural features and degradation behaviors of milled Fe and milled Fe5Mg suggest the effective dissolution of $\mathrm{Mg}$ in the Fe lattice. Based on the obtained results, it can be said that Fe5Mg powder would be a suitable candidate for non-permanent medical implants with a higher degradation rate than Fe.
\end{abstract}

Keywords: iron powder; magnesium powder; powder metallurgy; high energy processing; in vitro degradation

\section{Introduction}

Iron $(\mathrm{Fe})$ and magnesium $(\mathrm{Mg})$ are two of the most promising biodegradable, bioabsorbable, and biocompatible metals for temporary medical implants in vascular intervention and osteosynthesis applications [1-8]. Both elements are essential for living organisms and possess low toxicity.

Fe presents interesting mechanical properties that resemble those of SS316L, often used as coronary stent material $[9,10]$, but has a too-low degradation rate [11]. In order to obtain more suitable properties, different candidate alloying elements have been tested. Among them, $\mathrm{Mn}$ is the most investigated [2]. This element improves corrosion behavior, increases strength and elongation, and reduces magnetic susceptibility. Other elements that may confer some advantages are C, Si, Co, and Pd [4]. Powder metallurgical processing also may present some benefits, as it permits the combination of different elements and microstructures $[12,13]$. Electroforming technology is also able to improve Fe performance through the fine grain microstructure that it confers to the material [14]. 
Another approach to develop biodegradable implant materials is the use of $\mathrm{Mg}$ as a base metal $[8,15]$, which presents several distinct properties, among them, excellent biocompatibility, Young's modulus closer to that of human bones, which prevents stress yielding problems, and antibacterial properties [16-19]. However, the degradation rate of commercial purity $\mathrm{Mg}$ is far too fast. Several strategies have been successful in tailoring its corrosion [20] and degradation rate in order to adjust it to the rate needed for intended applications $[6,7,21,22]$. These are, among others, the use of high purity $\mathrm{Mg}$ and $\mathrm{Mg}$ alloys (Mg-Ca, Mg-Zn, and Mg-Ca-Zn) [23], the addition of rare earth elements [8] and the refinement and amorphization of the microstructure [24].

The present investigation starts from the hypothesis that a combination of both elements in solid solution in a Fe-rich range of the phase diagram may have suitable properties as material for biodegradable medical applications, with some advantages when compared with the bare metallic $\mathrm{Fe}$, i.e., faster degradation rate [4,25].

The critical point in the Fe-Mg system is that Fe and $\mathrm{Mg}$ are immiscible in solid state in the whole composition range. This represents a challenge when trying to synthesize a binary Fe-Mg solid solution, which requires the use of out-of-equilibrium processing techniques. Early attempts to prepare Fe-Mg were performed by alternate deposition [26] and co-evaporation [27] in ultrahigh vacuum, where thin films were obtained. Processing by high energy ball milling was faced in 1997 by Hightower et al. [28], having in mind hydrogen storage applications. They were able to produce single-phase bcc $\mathrm{Fe}(\mathrm{Mg})$ alloys with a concentration of up to about $20 \mathrm{at} \%(9.8 \mathrm{wt} \%) \mathrm{Mg}$. In 2004 and 2005, Dorofeev et al. [29] and Yelsukov et al. [30] presented a study on the kinetics of mechanical alloying and miscibility of this system. They found that the solid solution of $\mathrm{Mg}$ in Fe varied non-monotonically in a given range of $\mathrm{Mg}$ content. In 2007, Berziou et al. [31] explored the system $\mathrm{Fe}(1-\mathrm{x}) \mathrm{Mgx}, \mathrm{x} \leq 43.4 \mathrm{at} \%(25 \mathrm{wt} \%)$, as a candidate to act as sacrificial coating in the protection of steel structures. The processing method employed was the deposition of $\mathrm{Mg}$ by dc magnetron sputtering by which they obtained a solid solution of $\mathrm{Mg}$ in $\mathrm{Fe}$, of up to $25 \mathrm{at} \%$ (12.65 wt \%) of $\mathrm{Mg}$, whereas above this amount amorphization occurred.

The first time that Fe-Mg alloys were proposed for medical degradable applications was in a patent by Guangyin and Jialin [32] released in 2012, where it was claimed that powder metallurgical Fe-xMg alloys $(x=0.1-10 \mathrm{wt} \%)$ obtained by ball milling and consolidated by spark plasma sintering improves the degradation rate of the Fe matrix. Research that found an acceleration effect of $\mathrm{Mg}$ in combination with Fe employed a mixture of powders in a proportion of $\mathrm{Fe}$ to $\mathrm{Mg}$ of 99.5 to 0.5 [33]. A similar acceleration effect was obtained in a TCP composite loaded with $30 \mathrm{vol} \%$ of cold-sintered Fe-xMg ( $\mathrm{x}=30$ or 50 at\%) [34]. Xie et al. [35] compared the degradation rate of a consolidated ball milled Fe-30Mg at $\%$ (15.7 $\mathrm{wt}^{\mathrm{t}} \%$ ) alloy with that of pure $\mathrm{Mg}$ and concluded that their Fe-Mg alloy degraded slower. More recently, Shuai et al. [36] also found an acceleration effect of $\mathrm{Mg}$ on the degradation rate of an Fe matrix at a specific $\mathrm{Mg}$ concentration. The main objective of the present research is to process and characterize an Fe- $5 \mathrm{wt} \% \mathrm{Mg}$ alloy and Fe powders in order to investigate their degradation behavior in Hanks' pseudophysiological medium and separate the effects caused by high energy ball milling from those caused by the addition of $\mathrm{Mg}$ in a metastable solid solution. Special emphasis was put on determining the nature of the degradation products, which, to the authors' knowledge, is the first time they are reported.

The development of biocompatible absorbable Fe-Mg alloys with a faster degradation rate than Fe might enable the use of this material in a variety of applications, such as graft powder, reinforcing particles of biodegradable polymers, bulk material after consolidation, and feedstock for the additive manufacture of implants.

\section{Materials and Methods}

Spherical commercial Fe powder particles (99.7\% purity, diameter $\leq 74 \mu \mathrm{m}$ ) and spherical Mg powder particles (99.8\% purity, diameter $\leq 100 \mu \mathrm{m}$ ) were used in this investigation. 
For the $\mathrm{Fe} / \mathrm{Mg}$ ratio, a proportion of $95 \mathrm{wt} \%$ Fe to $5 \mathrm{wt} \% \mathrm{Mg}$ was selected, and the alloy will be referred to as Fe $5 \mathrm{Mg}$.

High energy ball milling of the Fe5Mg and Fe powders was carried out in a PM-4 Retsch planetary mill (Retsch $\mathrm{GmbH}$, Haan, Germany) at $200 \mathrm{rpm}$ for up to $16 \mathrm{~h}$ and the milled powders, named Fe5Mg16h and Fe16h. The ball (stainless steel, $20 \mathrm{~mm}$ diameter) to powder ratio was 7:1. In order to minimize oxidation during the milling process, the powders were introduced in stainless steel mill jars and sealed inside a glove box filled with argon. In addition to the Fe5Mg16h and Fe16h powders, a set of pure $\mathrm{Mg}$ was also ball milled following the same procedure and designated as Mg16h. As-received Fe powder was employed as reference materials. The selection of the Fe $5 \mathrm{Mg}$ composition was based on a preliminary study performed by the authors that suggested that this alloy presented the highest level of $\mathrm{Mg}$ in solid solution in the bcc Fe lattice given the absence of $\mathrm{Mg}$ peaks in the X-ray diffraction patterns and the highest interplanar distance compared with the other tested compositions. These results are shown in Tables S1 and S2 in the Supplementary Material.

Microstructural characterization was performed by scanning electron microscopy (SEM) (Hitachi High-Tech Corporation, Tokyo, Japan) with a HITACHI S4800 microscope equipped with energy dispersive $\mathrm{X}$-ray spectroscopy (EDS). To observe the cross sections, powders were cold mounted to avoid any phase transformation during the metallographic preparation. Final polishing was achieved with colloidal silica.

Identification of phases and determination of their weight fractions were performed by X-ray diffraction (XRD) with a Bruker AXS D8 diffractometer (Bruker, Billerica, MA, USA) equipped with a Co X-ray tube working at a current of $30 \mathrm{~mA}$ and a voltage of $40 \mathrm{kV}$. The XRD data were collected over a $2 \theta$ range of $30-120^{\circ}$ with a step size of $0.02^{\circ}$. Quantitative Rietveld analysis was performed and the phase fraction, crystallite size, and lattice parameters were calculated. It is worth mentioning that the Co X-ray tube is especially suited for iron-rich samples as it avoids interferences due to florescence, which do appear with the $\mathrm{Cu}$ X-ray tube, precluding the detection of Fe oxides.

Degradation behavior of the Fe5Mg16h, Fe16h, and Fe powders was studied in vitro by immersion of the powders in modified Hanks' solution ( $\mathrm{pH} 7.4)$ at $37^{\circ} \mathrm{C}$ for 3 and 14 days [37]. The powders with the solution in a ratio of $1 \mathrm{~g} / 50 \mathrm{~mL}$ were put in sealed polypropylene test tubes to avoid evaporation. After each immersion time, the powders were centrifuged $\mathrm{v}=6000 \mathrm{~min}^{-1}$ (Rotofix 32 Hettich) and the solid rich suspension deposited at the bottom of the FalconTM tubes was mixed with $70 \%$ ethanol solution, vortexed, and centrifuged again. This procedure was repeated twice before drying in a fume hood at room temperature. The $\mathrm{pH}$ evolution was measured every two days with a $\mathrm{pH}$ meter (Checker Plus, Hanna, Hanna Instruments, Woonsocket, RI, USA) with an error of \pm 0.05 .

The description of the milling process of the powders and the immersion degradation tests can be followed in the scheme provided in Figure 1.

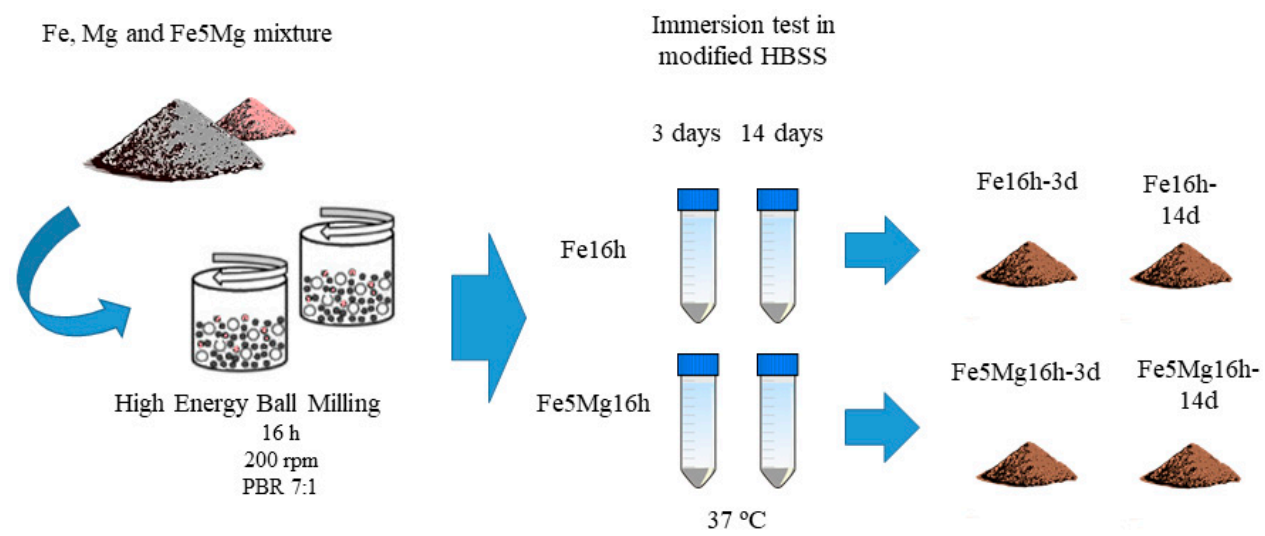

Figure 1. Scheme of the milling process and degradation test. 


\section{Results}

\subsection{Characterization of As-Milled Powders}

Figure 2 shows the cross section of Fe5Mg powder after $16 \mathrm{~h}$ of ball milling. The layered structure in Figure 2, that was also observed in Fe16h, is typical of a fracturing and cold-welding mechanism that further fractured due to work-hardening. Semiquantitative elemental analysis of a large area of the Fe $5 \mathrm{Mg} 16 \mathrm{~h}$ powder showed $\mathrm{Mg}$ contents in accordance with the nominal composition, indicating that no material was preferentially lost during processing.
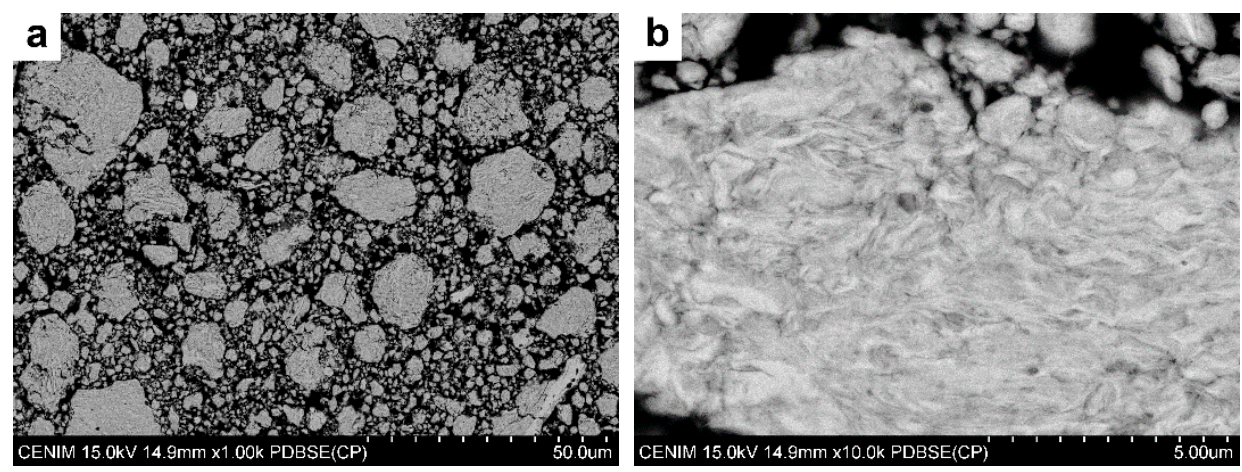

Figure 2. Cross sections of Fe5Mg powder ball milled for $16 \mathrm{~h}$. Backscattered scanning electron micrographs at low (a), and high (b) magnifications.

The milled Fe5Mg16h and Fe16h powders were analyzed by the Rietveld refinement of X-ray diffraction data. Figure 3 shows the XRD patterns of both milled powders together with the as-received Fe, Mg16h, and the as-received Mg. By comparing the milled and nonmilled unalloyed powders, it is evident that the high energy process caused a broadening of the peaks. This is a typical effect of milling, which produces a reduction in crystallite size and an increase in strain [38]. Table 1 lists the interplanar distances and crystallite sizes. There is no clear difference between interplanar distances of non-milled and milled powders both for Fe and $\mathrm{Mg}$. With respect to the crystallite size, ball milling reduces it significantly, from $>150 \mathrm{~nm}$ in the as-received powders to $15 \mathrm{~nm}(\alpha-\mathrm{Fe})$ in the milled Fe16h powder, and $46 \mathrm{~nm}(\mathrm{Mg})$ in the milled Mg16h powder, which confirms the capacity of high-energy processing in the formation of nanocrystallites. On the other hand, the Fe5Mg16h powder presents a four-time larger $\alpha$-Fe crystallite size, $69 \mathrm{~nm}$ against $15 \mathrm{~nm}$, which indicates that the presence of $\mathrm{Mg}$ restricts a further reduction of the alloy crystallite size.

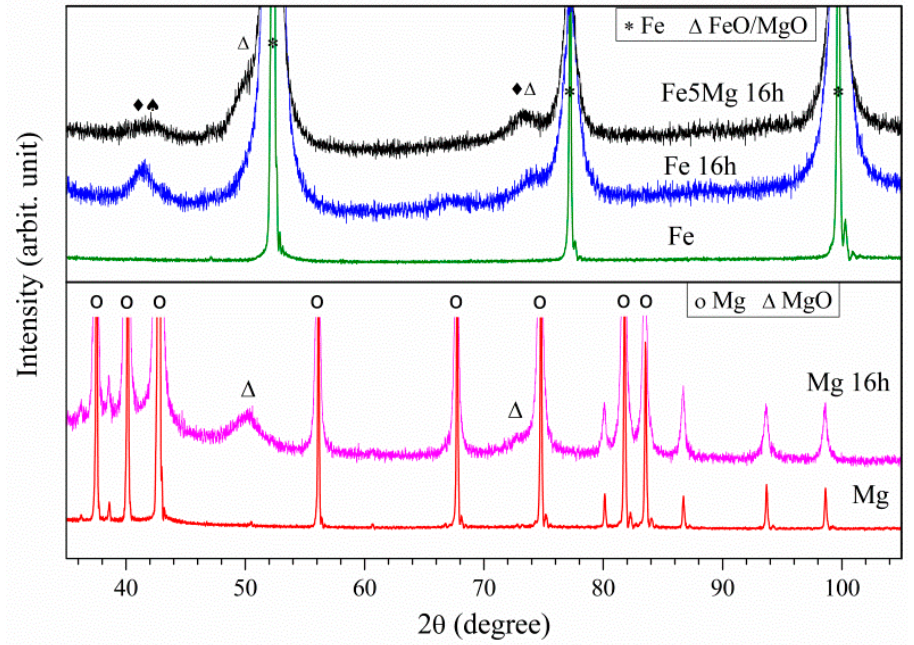

Figure 3. XRD of as-processed Fe5Mg16h, Fe16h, Fe, Mg16h, and Mg (arbitrary units). 
Table 1. Interplanar distances (ID, nm) corresponding to the [110] planes of $\alpha-\mathrm{Fe}$; and [11 $\overline{2} 0]$ and [0001] planes of $\mathrm{Mg}$; and crystallite sizes (CS, nm).

\begin{tabular}{cccccc}
\hline ID-CS & Fe & Fe16h & Fe5Mg16h & Mg & Mg16h \\
\hline ID $\alpha-F e$ & $0.2866 \pm 0.007$ & $0.2867 \pm 0.008$ & $0.2866 \pm 0.012$ & - & $0.3211 \pm 0.018$ \\
IDs Mg & - & - & - & $0.3208 \pm 0.009$ & $0.5212 \pm 0.019$ \\
\hline CS & $>150$ & 15 & 69 & $>150$ & 0.016 \\
\hline
\end{tabular}

After milling, some phases change in proportion and new ones appear. Phases and phase percentages, calculated from the X-ray diffraction patterns of the powders through Rietveld analysis program TOPAS (Bruker, Billerica, MA, USA), are shown in Table 2. By applying mass balance equations, it is possible to determine the amount of Fe or $\mathrm{Mg}$ that reacted during milling. In the as-received Fe powder, 16-h milling gave rise to the formation of $6 \mathrm{wt} \%$ magnetite $\left(\mathrm{Fe}_{3} \mathrm{O}_{4}\right)$. If only $\mathrm{Fe}$ atoms are considered, it results that the $6 \mathrm{wt} \% \mathrm{Fe}_{3} \mathrm{O}_{4}$ of the milled powder contains $4.4 \mathrm{wt} \%$ of the total amount of $\mathrm{Fe}$, which is the amount that reacted during milling to form part of the oxide phases, whereas $95.6 \%$ of the initial Fe remained as zero-valent Fe.

Table 2. Proportion of phases ( $w \mathrm{t} \%$ ) resulting from Rietveld analysis of as-processed and degraded $\mathrm{Fe}, \mathrm{Fe} 16 \mathrm{~h}$, and Fe5Mg16h powders for 3 and 14 days.

\begin{tabular}{|c|c|c|c|c|c|c|c|c|}
\hline \multirow[b]{2}{*}{ Sample } & \multicolumn{8}{|c|}{ Phases, wt $\%$} \\
\hline & $\alpha-\mathrm{Fe}$ & $\mathrm{Fe}_{3} \mathrm{O}_{4}$ & $\mathrm{MgFe}_{2} \mathrm{O}_{4}$ & $\gamma-\mathrm{FeO}(\mathrm{OH})$ & LDH * & $\mathrm{MgO} / \mathrm{FeO}$ & $\mathrm{Mg}$ & $\mathrm{MgO}$ \\
\hline \multicolumn{9}{|l|}{ As-received } \\
\hline $\mathrm{Fe}$ & 100 & - & - & - & - & - & - & - \\
\hline $\mathrm{Mg}$ & - & - & - & - & - & - & 98.8 & 1.2 \\
\hline \multicolumn{9}{|l|}{ As-processed } \\
\hline Fe16h & 94 & 6 & - & - & - & - & - & - \\
\hline Mg16h & - & - & - & - & - & - & 88 & 12 \\
\hline Fe5Mg16h & 93 & - & 1 & - & - & 6 & - & - \\
\hline \multicolumn{9}{|l|}{ Degraded 3d } \\
\hline Fe16h-3d & 94 & 6 & - & - & - & - & - & - \\
\hline Fe5Mg16h-3d & 88 & - & 7 & - & 5 & - & - & - \\
\hline \multicolumn{9}{|l|}{ Degraded 14d } \\
\hline Fe-14d & 99.80 & 0.20 & - & - & - & - & - & - \\
\hline Fe16h-14d & 39 & 55 & - & 6 & - & - & - & - \\
\hline Fe5Mg16h-14d & 40 & - & 25 & - & 35 & - & - & - \\
\hline
\end{tabular}

A similar calculation can be performed with the $\mathrm{Mg}$ powder to determine the amount of this element that oxidized during the milling process. In this case, the as-received powder was already slightly oxidized as $\mathrm{MgO}$ in an amount of $1.2 \mathrm{wt} \%$. This $1.2 \mathrm{wt} \% \mathrm{MgO}$ contains $0.7 \mathrm{wt} \%$ of the total $\mathrm{Mg}$ of the powder. After milling for $16 \mathrm{~h}(\mathrm{Mg} 16 \mathrm{~h})$, the amount of $\mathrm{MgO}$ increased up to $12 \mathrm{wt} \%$, which is equivalent to say that the amount of oxidized $\mathrm{Mg}$ increased from 0.7 to $7.6 \mathrm{wt} \%$, leaving $92.4 \mathrm{wt} \%$ of $\mathrm{Mg}$ unoxidized.

In the Fe5Mg16h powder, two new phases formed: $1 \mathrm{wt} \%$ of $\mathrm{MgFe}_{2} \mathrm{O}_{4}$ (magnesioferrite spinel), and $6 \mathrm{wt} \%$ of $\mathrm{MgO} / \mathrm{FeO}$ (periclase/wüstite). Given the uncertainty in the amount of $\mathrm{MgO}$ and $\mathrm{FeO}$, only ranges of $\mathrm{Fe}$ and $\mathrm{Mg}$ that oxidized as a result of milling can be established. Taking into account the amount of Fe and $\mathrm{Mg}$ oxidized during the milling of 
monolithic powders, the ranges for oxidized Fe and $\mathrm{Mg}$ would be from 4.4 to $4.9 \mathrm{wt} \%$ and from 13.4 to $7.6 \mathrm{wt} \%$, respectively. By considering these limits, it is possible to calculate that, from the $5 \mathrm{wt} \%$ of $\mathrm{Mg}$ of the initial powder, between 2.7 and $4.8 \mathrm{wt} \%$ is included in a solid solution in $\alpha$-Fe and the remaining 2.3 to $0.2 \mathrm{wt} \%$ reacted during milling and formed part of the two oxides $\left(\mathrm{MgFe}_{2} \mathrm{O}_{4}\right.$ and $\left.\mathrm{MgO}\right)$.

\subsection{Characterization of Degraded Powders}

The degradation study of Fe5Mg16h, Fe16h, and as-received Fe powders was performed by introducing a given amount of loose powder in Hanks' solution up to 14 days. A set of powders was cleansed, dried, and studied after 3 days of degradation, and another set after 14 days, when the experiment was finished. For the Fe5Mg16h powder, the reaction with the media started almost immediately and the solution acquired a brownish color after about $2 \mathrm{~h}$ of immersion, indicating the formation of oxides. As time increased, in addition to the turbidity of the media, the Fe5Mg16h sample showed an increasing amount of brownish powder. With regard to the $\mathrm{pH}$, it reached a value of $8.6 \pm 0.1$ after 3 days of immersion and remained invariant afterwards, indicating that the buffering capacity of the media was overwhelmed. A similar, although slower, process was observed in the beaker that contained the milled Fe16h powder. In this case, its $\mathrm{pH}$ increased up to $7.7 \pm 0.1$. In contrast, the as-received Fe powder did not suffer any visible change during the whole test and the $\mathrm{pH}$ of its solution remained at $7.4 \pm 0.05$. These results permit to draw a first conclusion about the sequence of the degradation rate of the studied powders from fast to slow as follows: Fe5Mg16h > Fe16h > Fe.

Following immersion tests, the degraded powders were cleaned, dried, and analyzed by SEM and XRD. Figure $4 \mathrm{a}, \mathrm{b}$ shows two micrographs of the cross section of the asreceived Fe powder that was submerged in Hanks' solution for 14 days (Fe-14d). At high magnification, a thin grey layer seems to be present around each particle. The corresponding EDS analysis performed in the middle of the powder particles (not shown) presented only a signal of Fe, whereas at their perimeters, some oxygen was detected. However, it was not possible to distinguish whether this oxygen came from the particle surface or from the resin of the mold.

XRD patterns of the degraded powders are presented in Figure 5 and the obtained phases listed in Table 2. Rietveld analysis of the XRD pattern of Fe-14d indicated that, effectively, there is a small amount of oxide $(0.2 \mathrm{wt} \%)$ in the form of magnetite $\left(\mathrm{Fe}_{3} \mathrm{O}_{4}\right)$, which was not detected in the non-degraded powder (see Table 2). Given the slow degradation reaction of the as-received Fe powder, no study was performed at 3 days of immersion.

Figure 4c,d shows SEM images of the Fe16h powder after immersion for 3 days in Hanks' solution (Fe16h-3d). A bright and grey phase can be distinguished. EDS analysis on these zones (not shown) indicated that the bright phase contains only Fe and that the darker one contains Fe and O. Rietveld analysis, Table 2 and Figure 5, shows the presence of $6 \mathrm{wt} \%$ of magnetite, almost the same amount as in the as-milled powder, indicating that after 3 days in Hanks' medium only limited degradation occurred.

Increasing immersion time of the Fe16h powder up to 14 days, Figure 4e,f, resulted in the formation of a large amount of oxides (Table 2 and Figure 5), i.e., $55 \mathrm{wt} \%$ of magnetite and $6 \mathrm{wt} \%$ of lepidocrocite $(\gamma-\mathrm{FeO}(\mathrm{OH}))$, the latter not detected in the other Fe powders. In addition to the bright $\alpha$-ferrite, SEM images revealed the presence of a phase that surrounded some granules, and particles that are independent of the granules, all of them with a similar grey contrast, which makes it difficult to distinguish between both reaction phases. From these results, it is evident that ball milling promoted a significant increase in the degradation rate of Fe powder, so that after 14 days of immersion, less than $40 \mathrm{wt} \%$ of Fe remained $\alpha$-ferrite.

The strong influence of the milling process on the degradation behavior of Fe powder can be rationalized by taking into account that milling introduces a high density of crystal defects [38] and promotes a reduction in grain/crystallite size (Table 1) and grain bound- 
aries. These defects act as easy paths for ion diffusion of the degradation medium, which results in an accelerated degradation rate.

Figure $4 \mathrm{~g}$, h shows SEM images of the Fe5Mg16h powder degraded for 3 days, where different grey contrasts are observed. A closer examination revealed the presence of a needle-like phase about $1 \mu \mathrm{m}$ long around the milled Fe5Mg granules, see Figure $4 \mathrm{~h}$. As listed in Table 2 and as shown in Figure 5, XRD indicates the presence of $88 \mathrm{wt} \% \alpha-\mathrm{Fe}$, $7 \mathrm{wt} \%$ of $\mathrm{MgFe}_{2} \mathrm{O}_{4}$, and $5 \mathrm{wt} \%$ of $\mathrm{Mg}_{0.75} \mathrm{Fe}_{0.25}[\mathrm{OH}]_{2}\left[\mathrm{CO}_{3}\right]_{0.125} \cdot 0.5\left[\mathrm{H}_{2} \mathrm{O}\right]$ (pyroaurite).
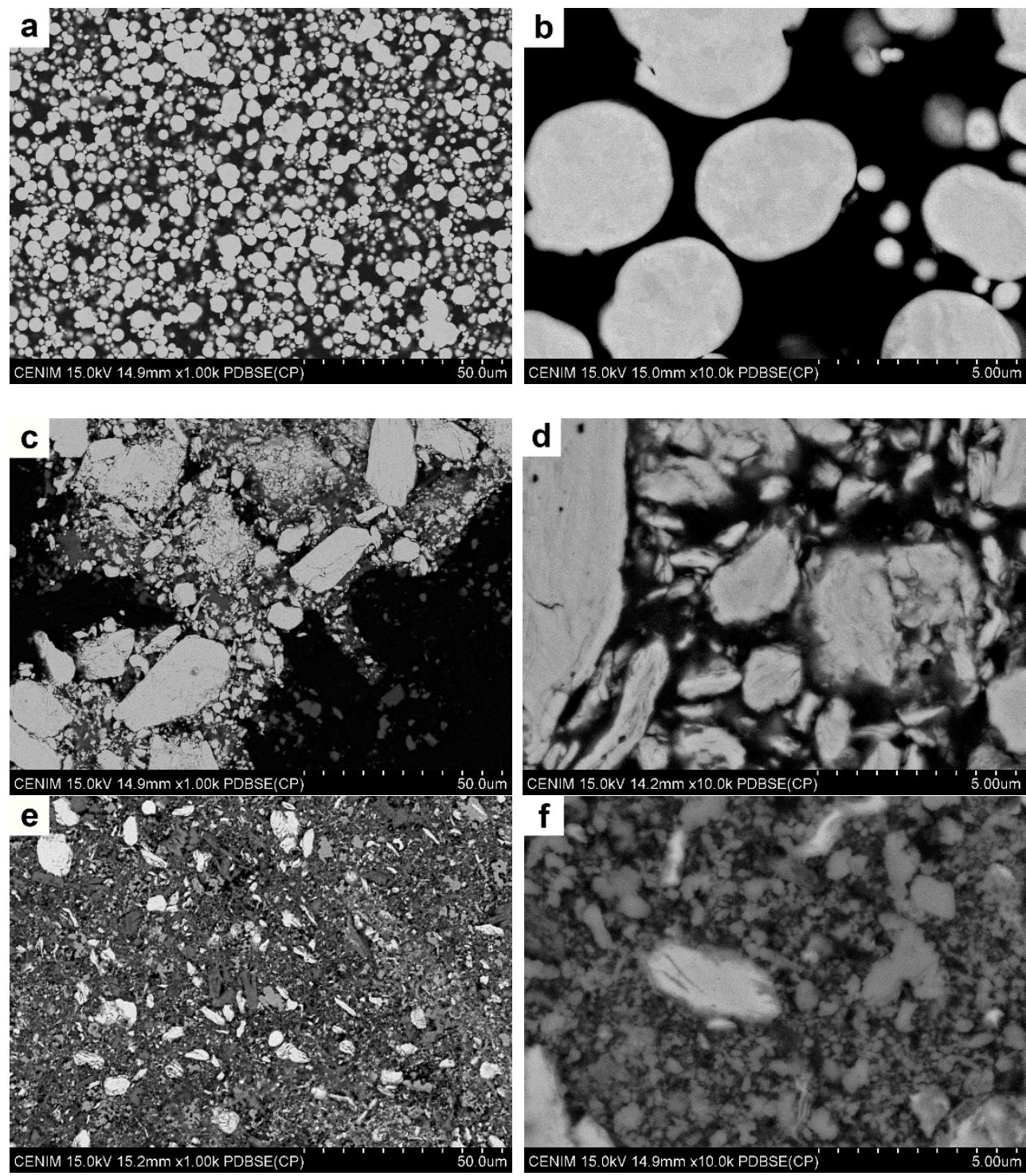

Figure 4. Cont. 

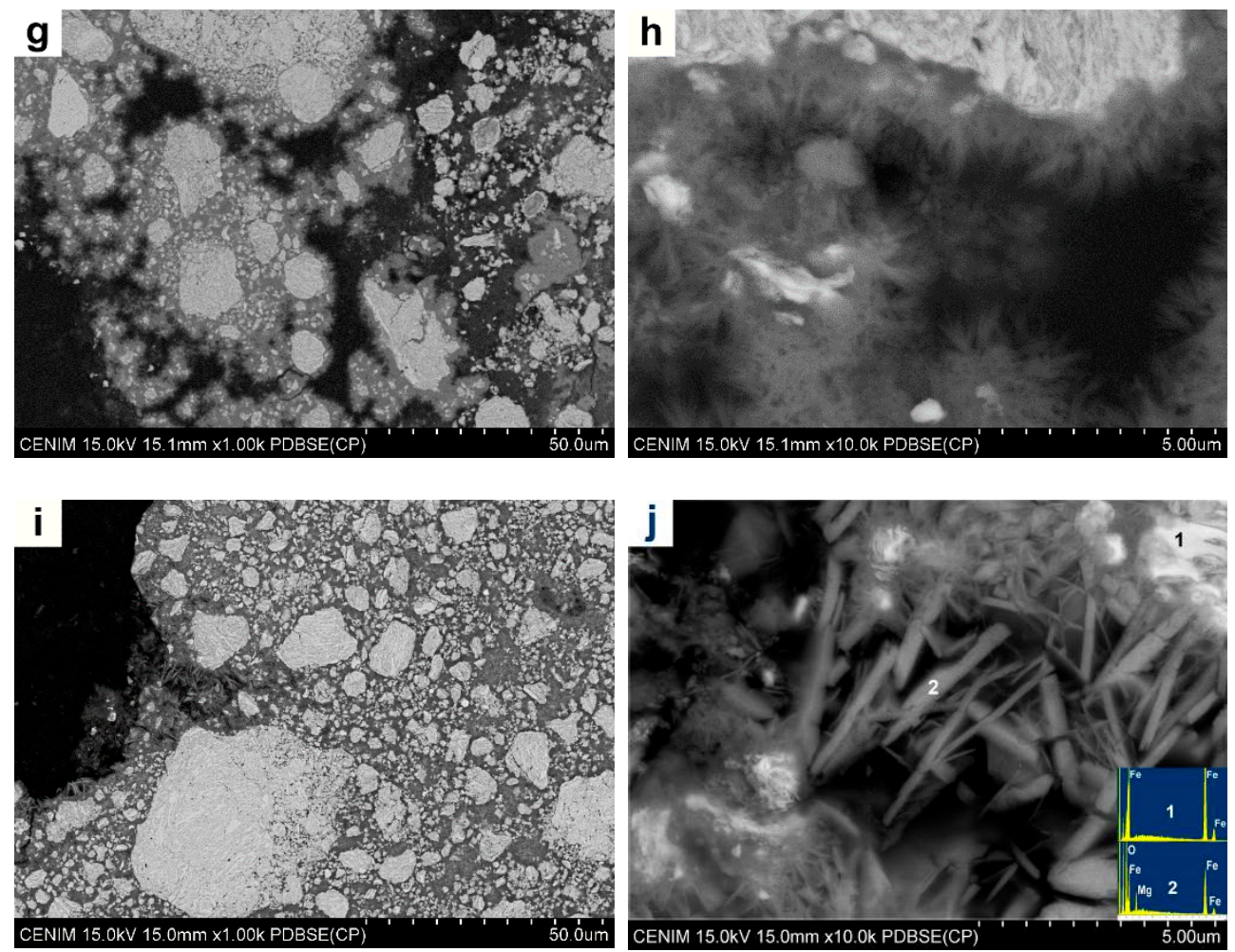

Figure 4. SEM micrographs of $(\mathbf{a}, \mathbf{b})$ as-received Fe powder degraded for 14 days; (c,d) SEM micrographs of Fe16h powder degraded for 3 days; (e,f) Fe16h powder degraded for 14 days; (g,h) Fe5Mg16h powder degraded for 3 days; and $(\mathbf{i}, \mathbf{j})$ Fe5Mg16h powder degraded for 14 days.

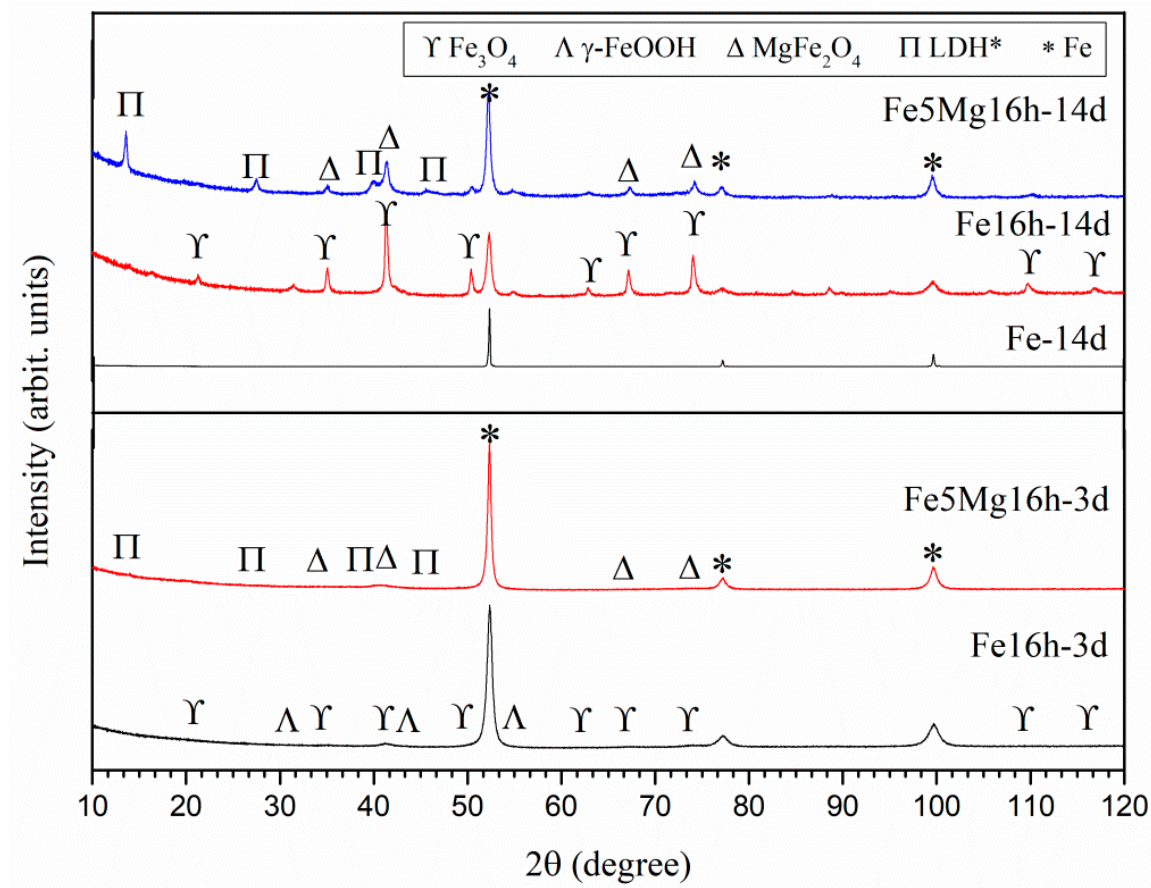

Figure 5. XRD of the degraded powders after 3 days (Fe5Mg16h and Fe16h-3d), and 14 days (Fe5Mg16h-14d, Fe16h-14d, and Fe-14d) of immersion in Hanks' solution. Arbitrary units. LDH*: $\mathrm{Mg}_{0.75} \mathrm{Fe}_{0.25}[\mathrm{OH}]_{2}\left[\mathrm{CO}_{3}\right]_{0.125} \cdot 0.5\left[\mathrm{H}_{2} \mathrm{O}\right]$.

Finally, Figure 4i,j shows micrographs of the Fe5Mg16h powder degraded for 14 days. As occurred with the Fe16h-14d powder, there is a noticeable increase of the greyish (oxide) 
phases and a decrease of the bright one ( $\alpha$-ferrite) when time of immersion in Hanks' solution increases from 3 to 14 days. The needle-like phase observed after three days of degradation suffered an increase in size and volume fraction, presenting a length of around $4 \mu \mathrm{m}$ and a width of about $500 \mathrm{~nm}$. According to XRD analysis, in this material, $\alpha$-ferrite accounts only for less than $40 \%$ of the weight of the degraded powder, being the remaining powder composed by $35 \mathrm{wt} \%$ of $\mathrm{MgFe}_{2} \mathrm{O}_{4}$ and $35 \mathrm{wt} \%$ of pyroaurite. Although the amount of $\alpha$-Fe is similar to that in Fe16h-14d, its result evident from the rapidly change in color of the solution that, during the first stages of immersion, the Fe5Mg16h alloy degraded faster than Fe16h. Some traces of $\mathrm{P}, \mathrm{Na}$, and $\mathrm{Cl}$ were also found when the samples were analyzed by EDS, but XRD did not show any crystalline phase related to them. The only evidence of a reaction that involves species present in the Hanks' solution appeared in the XRD pattern as an amorphous background that may be associated to ferrous phosphate precipitates [39], see Figure 5.

\section{Discussion}

\subsection{As-Milled Powders}

The goal pursued in this work was to process and characterize an Fe-Mg alloy with a higher degradation rate than pure Fe. In order to get a better insight into the possible degradation mechanisms, pure Fe and $\mathrm{Mg}$ were also processed.

After $16 \mathrm{~h}$ of milling, Fe16h crystallites reduced their size from $>150$ to $15 \mathrm{~nm}$, whereas $\mathrm{Mg} 16 \mathrm{~h}$ crystallites change from $>150$ to $46 \mathrm{~nm}$. In the case of $\mathrm{Mg}$, this is a saturation value, similar to that encountered by Hwang at al. [40], and Grosjean et al. [41], who employed analogous processing routes, and attributed this behavior to the high recovery rate of magnesium.

The powder formed by Fe and Mg particles is a ductile-brittle couple [38]. Thus, in the initial stages of milling, the Fe ductile metal particles get flattened and cold welded, and the $\mathrm{Mg}$ brittle particles get fragmented and trapped in the ductile particles. After enough milling, it is expected that the dispersion of the brittle particles become uniform or enter in solid solution in the Fe matrix, leading to chemical homogeneity. In the Fe5Mg16h powder (Table 1), the crystallite size of $\alpha$-Fe resulted to $69 \mathrm{~nm}$, more than four times larger than in Fe16h $(15 \mathrm{~nm})$, indicating a clear effect of the presence of $\mathrm{Mg}$ atoms. Shuai et al. [36] recently prepared Fe-Mg powder (10, 20,30 at \%) by high energy ball milling and obtained grain sizes of 19.3,12.5, and $11.7 \mathrm{~nm}$, clearly smaller than in the present case, which may be attributed to the different milling parameters (ball to powder ratio of 100:1, rotation speed of $300 \mathrm{rpm}$, and milling time of $40 \mathrm{~h}$ ).

Given the argon atmosphere under which the powders were milled, only limited oxidation occurred. For $\mathrm{Fe} 16 \mathrm{~h}$, the oxide was $\mathrm{Fe}_{3} \mathrm{O}_{4}(6 \mathrm{wt} \%)$ and for $\mathrm{Mg} 16 \mathrm{~h}$, was $\mathrm{MgO}$ (12 wt \%). In Fe5Mg16h, XRD patterns showed the presence of $\mathrm{MgFe}_{2} \mathrm{O}_{4}(1 \mathrm{wt} \%)$ and $\mathrm{MgO} / \mathrm{FeO}(6 \mathrm{wt} \%)$, but no $\mathrm{Mg}$ peaks. The absence of $\mathrm{Mg}$ signal indicates that some $\mathrm{Mg}$ entered in solid solution or the formation of a nanocrystalline structure, as proposed by Swain et al. [34], who prepared biocompatible $\beta$-TCP-based composites reinforced with iron-magnesium powder in proportion of about Fe- $5 \mathrm{Mg}$ and $\mathrm{Fe}-18 \mathrm{Mg}(\mathrm{wt} \%)$ by high energy milling and did not detect $\mathrm{Mg}$ peaks either.

A parameter to evaluate the suitability of the processing route employed in the present work is the amount of Fe and $\mathrm{Mg}$ that remained unoxidized after milling, see Table 2. In Fe16h, only $4.4 \%$ of Fe appeared in the form of magnetite, which results in $95.6 \%$ of unreacted $\mathrm{Fe}$, whereas in the Fe $5 \mathrm{Mg} 16 \mathrm{~h}$ powder, the unreacted $\mathrm{Fe}$ was between 94.7 and 95.6. Regarding $\mathrm{Mg} 16 \mathrm{~h}, 7.6 \%$ of $\mathrm{Mg}$ was associated with $\mathrm{MgO}$, i.e., $92.4 \%$ remained unoxidized, whereas in Fe5Mg16h, the unreacted $\mathrm{Mg}$ is between 86.3 and $92.4 \%$. The uncertainty in this case is due to the uncertainty in the ratio of $\mathrm{MgO} / \mathrm{FeO}$. In all cases, the proportion of metallic Fe and $\mathrm{Mg}$ in the milled powders was high and confirms the appropriateness of the processing route. These calculations on the composition of the starting powders aid in the analysis of their in vitro degradation behavior. 


\subsection{Degraded Powders}

Visual inspection of the immersed powders and XRD phase quantification, shown in Table 2, indicate that Fe5Mg16h exhibited the highest degradation rate followed by Fe16h and finally by Fe. It is interesting to note that the as-received Fe powder barely showed any sign of reaction after 14 days of immersion, when only about $0.2 \mathrm{wt} \%$ of $\mathrm{Fe}_{3} \mathrm{O}_{4}$ was detected. The Pourbaix diagram for the $\mathrm{Fe}-\mathrm{H}_{2} \mathrm{O}$ system predicts that oxidized species will be thermodynamically stable only under certain conditions of potential and $\mathrm{pH}$ [42]. More specifically, for the magnetite to form a relatively alkaline, $\mathrm{pH}$ is necessary. In consequence, it is reasonable that the small amount of oxidized solid species of Fe detected after 14 days of immersion was associated with the capacity of the Hanks' solution to buffer an increase of $\mathrm{pH}$, hindering the precipitation of a greater amount of $\mathrm{Fe}_{3} \mathrm{O}_{4}$.

In the case of the Fe16h, no significant differences in the amount of magnetite (6 wt $\%)$ was detected after 3 days of immersion with respect to that generated during ball milling $(6 \mathrm{wt} \%)$, and the rest of the solid phase remained as $\alpha$-Fe. It is known that ball milling introduces microstructural defects during the high energy processing [37]. This is what occurred to the Fe16h powders, as shown in Table 1, where ball milling of the as-received Fe reduced remarkably its crystallite size. Even though this factor is consistent with an increased reactivity and greater amounts of oxidized species after immersion testing, this was not observed. However, this does not mean that ball milling did not enhance the reactivity of the Fe16h powders, during the first three days of immersion. Following the previous rationale, it is reasonable to assume that for the 3-day testing period, the Hanks' solution buffered the $\mathrm{pH}$ conditions to an extent that still prevented magnetite formation. In addition, taking into account that for the as-received $\mathrm{Fe}$, the amount of $\mathrm{Fe}_{3} \mathrm{O}_{4}$ was one order of magnitude lower after longer immersion times, it is possible that any increase in the degradation of the Fe16h remained undetected due to the initial amount of magnetite formed mechanically during processing.

In contrast, after 14 days of immersion in Hanks' solution, only $47 \mathrm{wt} \%$ of the milled powder remained as $\alpha$-Fe and a remarkable increase of magnetite was detected ( $55 \mathrm{wt} \%$ ). This is consistent with an increased reactivity leading to enhanced degradation rates. As previously rationalized, this can be explained by a greater number of microstructural defects introduced during high-energy processing. A similar acceleration effect was observed by Bagherifard et al. [43], who promoted grain refinement by severe shot peening of pure iron sheets. Furthermore, the significant amount of $\mathrm{Fe}_{3} \mathrm{O}_{4}$ formed is consistent with the fact that the solution $\mathrm{pH}$ became more alkaline, favoring oxide precipitation. The degradation of Fe immersed in an aerated electrolyte is an electrochemical process in which the primary cathodic reaction is the reduction of dissolved oxygen, and this reaction results in the formation of hydroxyl ions that locally alkalize the environment. Furthermore, the buffer capacity of a solution depends on the concentration of the weak acid and its conjugate base in the buffer. In the modified Hanks' solution used in this investigation, the concentration of buffering species such as $\mathrm{NaHCO}_{3}, \mathrm{HEPES}$, and HEPES sodium salt were low. Consequently, it is likely that higher degradation rates and longer immersion times contributed to overwhelm the buffer capacity of the test solution, resulting in increasing $\mathrm{pH}$ values.

Interestingly, a new phase that was not found previously in the Fe-14d and Fe16h-3d powders was observed. Analysis of the XRD pattern of the Fe16h after 14 days of immersion (Figure 5) determined the presence of lepidocrocite $(\gamma-\mathrm{FeO}(\mathrm{OH}))$ to an extent of about a $6 \mathrm{wt} \%$. It is clear from the evolution of the solid oxides detected by XRD, during immersion of the as-received and the milled Fe powders, that the primary degradation species was $\mathrm{Fe}_{3} \mathrm{O}_{4}$, and that the milled condition $\gamma-\mathrm{FeO}(\mathrm{OH})$ appeared only after increasing immersion times. Therefore, even though lepidocrocite may come from the oxidation of zero-valent $\mathrm{Fe}$, it would also be a possibility that $\gamma-\mathrm{FeO}(\mathrm{OH})$ originated from the oxidation of $\mathrm{Fe}_{3} \mathrm{O}_{4}$. Unlike $\mathrm{Fe}_{3} \mathrm{O}_{4}$, which contains both ferrous $\left(\mathrm{Fe}^{2+}\right)$ and ferric $\left(\mathrm{Fe}^{3+}\right)$ ions, in lepidocrocite, all Fe content is fully oxidized. Consequently, the formation of $\gamma-\mathrm{FeO}(\mathrm{OH})$ requires an additional oxidation reaction. As commented above, $\mathrm{O}_{2}$ reduction is the primary cathodic 
reaction during Fe degradation. In environments where the availability of oxygen is limited, complete oxidation of $\mathrm{Fe}^{2+}$ to $\mathrm{Fe}^{3+}$ is reduced (or even inhibited). In this investigation, the milled powders were immersed in Hanks' solution inside sealed polypropylene test tubes to avoid evaporation. Therefore, replenishment of the dissolved $\mathrm{O}_{2}$ originally present in the Hanks' solution that was consumed during Fe oxidation (magnetite formation) was impeded. This limited the amount of $\mathrm{Fe}_{3} \mathrm{O}_{4}$ that further oxidized to $\gamma-\mathrm{FeO}(\mathrm{OH})$. Furthermore, lepidocrocite is known to be an oxidant species. Briefly, the ferric ions in $\gamma-\mathrm{FeO}(\mathrm{OH})$ can act as cathodic species and oxidize zero-valent $\mathrm{Fe}$ to form $\mathrm{Fe}^{2+}$ ions $[44,45]$, and transform to $\mathrm{Fe}_{3} \mathrm{O}_{4}$. For instance, Kassim et al. [46] observed $\gamma-\mathrm{FeO}(\mathrm{OH})$ as a reaction product of iron in an aqueous environment and found that its amount in relation to $\mathrm{Fe}_{3} \mathrm{O}_{4}$ depended on the rate of oxidation and the concentration of dissolved oxygen. These factors contribute to explain the remarkable amount of $\mathrm{Fe}_{3} \mathrm{O}_{4}$ formed during 14 days of immersion of the Fe16h in comparison with the lower formation of $\gamma-\mathrm{FeO}(\mathrm{OH})$.

In contrast with the Fe and Fe16h powders, the mechanically alloyed Fe-Mg powder prepared in the present work produced $\mathrm{Mg}$-containing phases as degradation products. More specifically, magnesium ferrite $\left(\mathrm{MgFe}_{2} \mathrm{O}_{4}\right)$ and pyroaurite $\left(\mathrm{Mg}_{0.75} \mathrm{Fe}_{0.25}[\mathrm{OH}]_{2}\right.$ $\left.\left[\mathrm{CO}_{3}\right]_{0.125} \cdot 0.5\left[\mathrm{H}_{2} \mathrm{O}\right]\right)$. Compounds of the type pyroaurite are known as layered double hydroxides (LDHs), and they can be generally written as $\left[\mathrm{M}(\mathrm{II})_{1-\mathrm{x}} \mathrm{M}(\mathrm{III})_{\mathrm{x}}(\mathrm{OH})_{2}\right]^{\mathrm{x}+}\left[\left(\mathrm{A}^{\mathrm{n}-}\right.\right.$ $\left.\mathrm{x} / \mathrm{n}) \cdot \mathrm{mH}_{2} \mathrm{O}\right]^{\mathrm{x}-}$ in which $\mathrm{M}(\mathrm{II})$ and $\mathrm{M}(\mathrm{III})$ represent a divalent or trivalent metal cation and An is the anion. LDHs are structures organized in stacked sheets, where the cations reside, while the anion and water move freely in the interlayer region, breaking and forming new bonds [47]. Their crystalline structure can be rhombohedral, like in the case of pyroaurite, or hexagonal (sjögrenite) [48]. Due to their large surface area and their capability of carrying positive charges on the surface, they are used as adsorbents [49]. They have good biocompatibility and low toxicity [50], which make them possible candidates for biomedical applications. On the other hand, $\mathrm{MgFe}_{2} \mathrm{O}_{4}$ is a brownish black spinel that belongs to the magnetite series. It is a soft magnetic material used in catalysis, fuel cells, supercapacitor electrodes, microwave devices, etc. [51-53]. The nanoparticles are not cytotoxic, present magnetization, and exhibit induction heating. In addition, similar materials [36] showed good cytocompatibility and cell viability. Nevertheless, as some authors expressed [54], there is a concern about the evaluation of Fe-based implants and a thorough analysis is still needed.

Synthesis of $\mathrm{MgFe}_{2} \mathrm{O}_{4}$ has been a subject of interest in the recent years. It is produced conventionally by solid state reactions of oxide or carbonate mixtures at elevated temperatures, such as $1100{ }^{\circ} \mathrm{C}$ or higher $[55,56]$. Other production methods such as coprecipitation [57], combustion [58], mechanosynthesis [59], electrospinning [60], and hydrothermal synthesis [61] have also shown to be successful. In the present investigation, an amount of about $1 \mathrm{wt} \% \mathrm{MgFe}_{2} \mathrm{O}_{4}$ formed from the Fe5Mg after $16 \mathrm{~h}$ of high energy milling. This is consistent with previous independent works where polycrystalline $\mathrm{MgFe}_{2} \mathrm{O}_{4}$ was prepared by ball milling [62]. Besides, as previously commented either $\mathrm{FeO}$ or $\mathrm{MgO}$ also formed during milling of the powders.

Table 2 shows that after 3 days of immersion of Fe5Mg16h, similar amounts of $\mathrm{MgFe}_{2} \mathrm{O}_{4}$ and $\mathrm{MgFe}-\mathrm{LDH}$ appeared. All preparation methods of $\mathrm{MgFe}_{2} \mathrm{O}_{4}$ commented on the above-required higher temperatures than that used for degradation in the present study $\left(37^{\circ} \mathrm{C}\right)$. However, $\mathrm{Xu}$ et al. [63] presented a new method for the preparation of $\mathrm{MgFe}_{2} \mathrm{O}_{4}$ by aging a suspension of $\mathrm{MgFe}-\mathrm{LDH}$ at temperatures below $100{ }^{\circ} \mathrm{C}$. They observed the conversion of the $\mathrm{MgFe}-\mathrm{LDH}$ to $\mathrm{MgFe} 2 \mathrm{O} 4$ at temperatures as low as $40^{\circ} \mathrm{C}$. Furthermore, calculation of the $\Delta \mathrm{H}_{\mathrm{f}}{ }^{\circ}$ and $\Delta \mathrm{G}_{\mathrm{f}}{ }^{\circ}$ at $25^{\circ} \mathrm{C}$ of $\mathrm{MgFe}_{2} \mathrm{O}_{4}$ were determined to be lower than those of the $\mathrm{MgFe}-\mathrm{LDH}$, which indicates that $\mathrm{MgFe}_{2} \mathrm{O}_{4}$ is more stable than the corresponding $\mathrm{MgFe}-\mathrm{LDH}$. In contrast, $\mathrm{MgFe}-\mathrm{LDH}$ can be easily prepared by coprecipitation of the two metals at a high $\mathrm{pH}$ [64]. It is important to note that alternatively to the oxygen reduction reaction being the main cathodic reaction during Fe degradation, hydrogen evolution $(\mathrm{HE})$ is the primary cathodic reaction during $\mathrm{Mg}$ dissolution. This is due to the low corrosion potential normally exhibited by $\mathrm{Mg}$, far below the reversible potential for HE. This reaction 
produces hydroxyl ions which, in addition to the high chemical activity of $\mathrm{Mg}$, are likely to rapidly alkalize the environment close to the degrading powders. In consequence, it is proposed here that during the immersion of Fe5Mg16h, MgFe-LDH formed first and that the amount of magnesium ferrite found was the sum of that originated mechanically by ball milling (before testing) and by thermostatic conversion of the MgFe-LDH with the time of exposure to the test solution. Finally, when the time of immersion increased to 14 days, greater amounts of both Mg-Fe containing phases were measured.

Interestingly, no trace of the Fe oxidized species found during degradation of Fe and Fe16h were detected. It is reasonable that the dissolved species of Fe that originated due to degradation of the Fe5Mg16h followed the pathway proposed above, contributing to the formation of $\mathrm{MgFe}-\mathrm{LDH}$ instead of $\mathrm{Fe}_{3} \mathrm{O}_{4}$ and $\gamma-\mathrm{FeO}(\mathrm{OH})$.

Other examples of degradation studies of Fe-Mg materials are found in Swain et al. [34], Sikora-Jasinska et al. [39,65,66], and Shuai et al. [36]. Swain et al. [34] studied degradation in Ring's solution of $\beta$-TCP-based composites reinforced with the Fe-Mg powder and observed $\mathrm{Fe}_{3} \mathrm{O}_{4}$ and $\mathrm{Mg}(\mathrm{OH})$ phases as reaction products. They did not observe any phase that contained both Fe and $\mathrm{Mg}$, which may be due to the annealing at $400{ }^{\circ} \mathrm{C}$ that was applied to the samples, which may have induced the segregation of components and even the formation of oxides before the immersion test. Sikora-Jasinska et al. $[39,65,66]$ studied degradation in Hanks' medium of $\mathrm{Fe} / \mathrm{Mg}_{2} \mathrm{Si}$ composites obtained by ball milling the individual powders followed by consolidation through hot rolling, and found some $\alpha-\mathrm{FeO}(\mathrm{OH})$ and $\mathrm{FeCO}_{3}$, but no particles containing Fe and $\mathrm{Mg}$. Finally, Shuai et al. [36] prepared Fe-Mg compacted samples and studied their degradation rate in simulated body fluid $(\mathrm{SBF})$. Although reaction products were not defined, they also observed an increase in degradation of compacted Fe-Mg powder in comparison with Fe. Their maximum degradation rate occurred in the alloy with $20 \mathrm{at} \% \mathrm{Mg}(9.8 \mathrm{wt} \%)$, the one that retained, after milling, $8.5 \mathrm{at} \% \mathrm{Mg}(3.9 \mathrm{wt} \%)$ in solid solution, slightly less than the $5 \mathrm{wt} \%$ in the present case.

Based on the preceding results and discussion it can be stated that the Fe5Mg16h powder obtained in this work, as it degrades faster than Fe powder, seems worth to be considered for further research as bioabsorbable implant material. Possible applications of the powder in the biomedical field would be as grafting material, for hyperthermia treatments, as drug delivery vehicle, as a reinforcing element of biodegradable polymer implants, as bulk material after consolidation, and as feedstock for additive manufacture of porous implants.

There remains a number of issues that deserve deeper investigation, such as its possible antibacterial or osteoinduction effects in comparison with Fe16h, which also proved to degrade faster than the as-received Fe powder, or the employment of different processing methods to produce Fe-Mg alloys in different ways, and the effect of postprocessing to obtain partially fully-consolidated material that might be suitable to be considered for non-permanent medical implants.

\section{Conclusions}

Fe-5 wt \% Mg (Fe5Mg) and Fe powders were processed by high energy planetary ball-milling for $16 \mathrm{~h}$, and characterized as-milled and after immersion in Hanks' solution for up to 14 days. Special emphasis was put on determining the nature of the degradation products and in comparing the degradation behavior of Fe5Mg16h with that of Fe16h and as-received Fe powder in order to distinguish the effects due to high energy processing from those due to the presence of $\mathrm{Mg}$. The results showed that:

- $\quad$ Due to high energy ball milling, crystallite sizes decrease from >150 nm to $69 \mathrm{~nm}$ in Fe5Mg16h and to $15 \mathrm{~nm}$ in Fe16h;

- Only limited oxidation occurred during milling, which confirms the appropriateness of the processing route;

- $\quad$ The absence of Mg peaks in XRD patterns of Fe5Mg16h suggests the presence of $\mathrm{Mg}$ atoms in solid solution within the Fe lattice; 
- Static immersion tests showed that the Fe5Mg milled powder degrades faster than milled $\mathrm{Fe}$, and that both powders degrade much faster than as-received Fe. The distortion that $\mathrm{Mg}$ produced in the Fe structure, together with the increase in structural defects introduced by the processing route are proposed as the main mechanisms that promoted this increased degradation rate of the Fe5Mg alloy with respect to Fe;

- $\quad$ The degradation products of milled Fe powder were $\mathrm{Fe}_{3} \mathrm{O}_{4}$ and $\gamma-\mathrm{FeO}(\mathrm{OH}$. This can be explained in terms of the absence of $\mathrm{O}_{2}$ during the experiments;

- $\quad$ The degradation products of milled Fe5Mg powder were $\mathrm{MgFe}_{2} \mathrm{O}_{4}$ and $\mathrm{Mg}_{0.75} \mathrm{Fe}_{0.25}$ $[\mathrm{OH}]_{2}\left[\mathrm{CO}_{3}\right]_{0.125} \cdot 0.5\left[\mathrm{H}_{2} \mathrm{O}\right]$;

- The fact that the immersion of Fe5Mg16h in Hanks' solution generated reaction products that are known to present good biocompatibility and low toxicity, which makes this material a suitable candidate for biomedical applications.

Supplementary Materials: The following are available online at https:/ /www.mdpi.com/article/10 $.3390 /$ met12010078/s1. Table S1: Interplanar distance, $\mathrm{d}(\mathrm{nm}), \mathrm{of} \mathrm{Fe-xMg}$ powders $(\mathrm{x}=1,3,5,7 \mathrm{wt} \%)$ milled for 2, 8 and $16 \mathrm{~h}$, corresponding to the [110] planes of $\mathrm{Fe}$, and variation, $\Delta \mathrm{d}$, with respect to the as-received Fe powder $\left(d_{\mathrm{Fe}}=0.28659 \AA\right)$. Table S2: Weight percent of Mg phase in each alloy for each milling time.

Author Contributions: R.G.E.: Validation, Investigation, Writing-Original Draft, Data curation, Visualization; M.M.: Conceptualization, Methodology, Writing_-Original Draft, Supervision; S.F.: Writing-Original Draft; M.L.: Conceptualization, Methodology, Investigation, Writing-Original Draft, Visualization, Supervision, Project administration, Funding acquisition; J.R.: Funding acquisition. All authors have read and agreed to the published version of the manuscript.

Funding: Financial support of the Ministry of Science and Innovation of Spain (MICINN) PID2019104351GB-C21, PCIN-2017-036 (M-era.Net2016:4128, EU-FEDER), and RTI2018-096391-B-C31, and Comunidad de Madrid ADITIMAT-CM (S2018/NMT-4411) are greatly acknowledged. R. Estrada thanks MICINN for FPI grant PRE2020-092118, and S. Fajardo expresses his gratitude to the State Research Agency (MICINN), the Spanish National Research Council (CSIC), and the European Regional Development Fund (ERDF) for their support under project RYC2019-027006-I (AEI/FEDER/UE).

Data Availability Statement: Mendeley Data, V1, https://doi.org/10.17632/y3c35xrhbb.1 (accessed on 26 December 2021).

Acknowledgments: The authors thank J.A. Jiménez and I. Llorente (XRD), M. Maher and A. Tomás (SEM-EDS), M. Acedo (machining), and students J. Colchero, A. Cardeña, and C. RodríguezCastañeda (BM).

Conflicts of Interest: The authors declare no conflict of interest.

\section{References}

1. Peuster, M.; Wohlsein, P.; Brügmann, M.; Ehlerding, M.; Seidler, K.; Fink, C.; Brauer, H.; Fischer, A.; Hausdorf, G.; Care, I. A novel approach to temporary stenting: Degradable cardiovascular stents produced from corrodible metal-Results 6-18 months after implantation into New Zealand white rabbits. Heart 2001, 1000, 563-569. [CrossRef] [PubMed]

2. Hermawan, H.; Dubé, D.; Mantovani, D. Development of Degradable Fe-35Mn Alloy for Biomedical Application. In Advanced Materials Research; Trans Tech Publications Ltd.: Bach, Switzerland, 2006; pp. 107-112. [CrossRef]

3. Hermawan, H.; Dubé, D.; Mantovani, D. Developments in metallic biodegradable stents. Acta Biomater. 2010, 6, 1693-1697. [CrossRef]

4. Schinhammer, M.; Hänzi, A.C.; Löffler, J.F.; Uggowitzer, P.J. Design strategy for biodegradable Fe-based alloys for medical applications. Acta Biomater. 2010, 6, 1705-1713. [CrossRef]

5. Witte, F.; Kaese, V.; Haferkamp, H.; Switzer, E.; Meyer-Lindenberg, A.; Wirth, C.J.; Windhagen, H. In vivo corrosion of four magnesium alloys and the associated bone response. Biomaterials 2005, 26, 3557-3563. [CrossRef]

6. Witte, F.; Fischer, J.; Nellesen, J.; Crostack, H.A.; Kaese, V.; Pisch, A.; Beckmann, F.; Windhagen, H. In vitro and in vivo corrosion measurements of magnesium alloys. Biomaterials 2006, 27, 1013-1018. [CrossRef] [PubMed]

7. Zheng, Y.F.F.; Gu, X.N.N.; Witte, F. Biodegradable metals. Mater. Sci. Eng. R Rep. 2014, 77, 1-34. [CrossRef]

8. Han, H.S.; Loffredo, S.; Jun, I.; Edwards, J.; Kim, Y.C.; Seok, H.K.; Witte, F.; Mantovani, D.; Glyn-Jones, S. Current status and outlook on the clinical translation of biodegradable metals. Mater. Today 2019, 23, 57-71. [CrossRef]

9. Balcon, R. Recommendations on stent manufacture, implantation and utilization. Eur. Heart J. 1997, 18, 1536-1547. [CrossRef] 
10. Hu, T.; Yang, C.; Lin, S.; Yu, Q.; Wang, G. Biodegradable stents for coronary artery disease treatment: Recent advances and future perspectives. Mater. Sci. Eng. C 2018, 91, 163-178. [CrossRef]

11. Venezuela, J.; Dargusch, M.S. Addressing the slow corrosion rate of biodegradable Fe-Mn: Current approaches and future trends. Curr. Opin. Solid State Mater. Sci. 2020, 24, 100822. [CrossRef]

12. Wegener, B.; Sievers, B.; Utzschneider, S.; Müller, P.; Jansson, V.; Rößler, S.; Nies, B.; Stephani, G.; Kieback, B.; Quadbeck, P. Microstructure, cytotoxicity and corrosion of powder-metallurgical iron alloys for biodegradable bone replacement materials. Mater. Sci. Eng. B Solid-State Mater. Adv. Technol. 2011, 176, 1789-1796. [CrossRef]

13. Gorejová, R.; Haverová, L.; Oriňaková, R.; Oriňak, A.; Oriňak, M. Recent advancements in Fe-based biodegradable materials for bone repair. J. Mater. Sci. 2019, 54, 1913-1947. [CrossRef]

14. Moravej, M.; Mantovani, D. Biodegradable metals for cardiovascular stent application: Interests and new opportunities. Int. J. Mol. Sci. 2011, 12, 4250-4270. [CrossRef]

15. Staiger, M.P.; Pietak, A.M.; Huadmai, J.; Dias, G. Magnesium and its alloys as orthopedic biomaterials: A review. Biomaterials 2006, 27, 1728-1734. [CrossRef] [PubMed]

16. Robinson, D.A.; Griffith, R.W.; Shechtman, D.; Evans, R.B.; Conzemius, M.G. In vitro antibacterial properties of magnesium metal against Escherichia coli, Pseudomonas aeruginosa and Staphylococcus aureus. Acta Biomater. 2010, 6, 1869-1877. [CrossRef]

17. Zeng, J.; Ren, L.; Yuan, Y.; Wang, Y.; Zhao, J.; Zeng, R.; Yang, K.; Mei, X. Short-term effect of magnesium implantation on the osteomyelitis modeled animals induced by Staphylococcus aureus. J. Mater. Sci. Mater. Med. 2013, 24, 2405-2416. [CrossRef]

18. Rodríguez-Sánchez, J.; Pacha-Olivenza, M.Á.; González-Martín, M.L. Bactericidal effect of magnesium ions over planktonic and sessile Staphylococcus epidermidis and Escherichia coli. Mater. Chem. Phys. 2019, 221, 342-348. [CrossRef]

19. Pacha-Olivenza, M.A.A.; Galván, J.C.C.; Porro, J.A.A.; Lieblich, M.; Díaz, M.; Angulo, I.; Cordovilla, F.; García-Galván, F.R.R.; Fernández-Calderón, M.C.C.; González-Martín, M.L.L.; et al. Efficacy of laser shock processing of biodegradable Mg and Mg-1Zn alloy on their in vitro corrosion and bacterial response. Surf. Coat. Technol. 2020, 384, 125320. [CrossRef]

20. Song, G. Control of biodegradation of biocompatable magnesium alloys. Corros. Sci. 2007, 49, 1696-1701. [CrossRef]

21. Chen, Y.; Xu, Z.; Smith, C.; Sankar, J. Recent advances on the development of magnesium alloys for biodegradable implants. Acta Biomater. 2014, 10, 4561-4573. [CrossRef]

22. Zhao, D.; Witte, F.; Lu, F.; Wang, J.; Li, J.; Qin, L. Current status on clinical applications of magnesium-based orthopaedic implants: A review from clinical translational perspective. Biomaterials 2017, 112, 287-302. [CrossRef]

23. Cihova, M.; Martinelli, E.; Schmutz, P.; Myrissa, A.; Schäublin, R.; Weinberg, A.M.; Uggowitzer, P.J.; Löffler, J.F. The role of zinc in the biocorrosion behavior of resorbable Mg-Zn-Ca alloys. Acta Biomater. 2019, 100, 398-414. [CrossRef]

24. Kiani, F.; Wen, C.; Li, Y. Prospects and strategies for magnesium alloys as biodegradable implants from crystalline to bulk metallic glasses and composites-A review. Acta Biomater. 2020, 103, 1-23. [CrossRef] [PubMed]

25. Multigner, M.; Lieblich, M.; González-Carrasco, J.L.; Rodríguez-Castañeda, C.; Cardeña, A.; de la Presa, P.; Rams, J. Characterisation of planetary ball-milled Fe-Mg powder. In Proceedings of the 11th International Symposium on Biodegradable Metals for Biomedical Applications, Alicante, Spain, 25-30 August 2019.

26. Kawaguchi, K.; Yamamoto, R.; Hosoito, N.; Shinjo, T.; Takada, T. Magnetic Properties of Fe-Mg Artificial Superstructure Films. J. Phys. Soc. Jpn. 1986, 55, 2375-2383. [CrossRef]

27. Fnidiki, A.; Eymery, J.E.; Denanot, M.E.; de Mdtal, L.; Pineau, R.; Poitiers, F. Structure and stability of Fe-Mg amorphous alloys prepared by coevaporation. Hyperfine Interact. 1989, 45, 295-300. [CrossRef]

28. Hightower, A.; Fultz, B.; Bowman, R.C. Mechanical alloying of Fe and Mg. J. Alloys Compd. 1997, 252, 238-244. [CrossRef]

29. Dorofeev, G.A.; Elsukov, E.P.; Ul'anov, A.L. Mechanical Alloying of Immiscible Elements in the Fe-Mg System. Inorg. Mater. 2004, 40, 690-699. [CrossRef]

30. Yelsukov, E.P.; Dorofeev, G.A.; Ulyanov, A.L. Mechanism and kinetics of mechanical alloying in an immiscible Fe-Mg system. Czechoslov. J. Phys. 2005, 55, 913-921. [CrossRef]

31. Berziou, C.; Remy, K.; Billard, A.; Creus, J. Corrosion behavior of dc magnetron sputtered Fe1-xMgx alloy films in 3 wt $\{\%\}$ NaCl solution. Corros. Sci. 2007, 49, 4276-4295. [CrossRef]

32. Guangyin, Y.; Jialin, N. Medical degradable Fe-Mg Binary Alloy Material and Preparation Method Thereof. Chinese Patent CN103028149B, 27 August 2012.

33. Oriňáková, R.; Oriňák, A.; Bučková, L.M.; Giretová, M.; Medveckỳ, L.; Labbanczová, E.; Kupková, M.; Hrubovčáková, M.; Koval, K. Iron based degradable foam structures for potential orthopedic applications. Int. J. Electrochem. Sci. 2013, 8, 12451-12465.

34. Swain, S.K.; Gotman, I.; Unger, R.; Kirkpatrick, C.J.; Gutmanas, E.Y. Microstructure, mechanical characteristics and cell compatibility of $\$ \beta \$$-tricalcium phosphate reinforced with biodegradable Fe-Mg metal phase. J. Mech. Behav. Biomed. Mater. 2016, 53, 434-444. [CrossRef]

35. Xie, G.; Takada, H.; Kanetaka, H. Development of high performance MgFe alloy as potential biodegradable materials. Mater. Sci. Eng. A 2016, 671, 48-53. [CrossRef]

36. Shuai, C.; He, C.; Qian, G.; Min, A.; Deng, Y.; Yang, W.; Zang, X. Mechanically driving supersaturated Fe-Mg solid solution for bone implant: Preparation, solubility and degradation. Compos. Part B Eng. 2021, 207, 108564. [CrossRef]

37. Lévesque, J.; Hermawan, H.; Dubé, D.; Mantovani, D. Design of a pseudo-physiological test bench specific to the development of biodegradable metallic biomaterials. Acta Biomater. 2008, 4, 284-295. [CrossRef]

38. Suryanarayana, C. Mechanical alloying and milling. Prog. Mater. Sci. 2001, 46, 1-184. [CrossRef] 
39. Sikora-Jasinska, M.; Chevallier, P.; Turgeon, S.; Paternoster, C.; Mostaed, E.; Vedani, M.; Mantovani, D. Long-term in vitro degradation behavior of $\mathrm{Fe}$ and $\mathrm{Fe} / \mathrm{Mg}_{2} \mathrm{Si}$ composites for biodegradable implant applications. RSC Adv. 2018, 8, 9627-9639. [CrossRef]

40. Hwang, S.; Nishimura, C.; McCormick, P.G. Mechanical milling of magnesium powder. Mater. Sci. Eng. A 2001, 318, 22-33. [CrossRef]

41. Grosjean, M.H.; Zidoune, M.; Roué, L.; Huot, J.; Schulz, R. Effect of ball milling on the corrosion resistance of magnesium in aqueous media. Electrochim. Acta 2004, 49, 2461-2470. [CrossRef]

42. Pourbaix, M. Atlas of Electrochemical Equilibria in Aqueous Solutions; National Association of Corrosion Engineers: Houston, TX, USA, 1984.

43. Bagherifard, S.; Molla, M.F.; Kajanek, D.; Donnini, R.; Hadzima, B.; Guagliano, M. Accelerated biodegradation and improved mechanical performance of pure iron through surface grain refinement. Acta Biomater. 2019, 98, 88-102. [CrossRef] [PubMed]

44. Antony, H.; Legrand, L.; Maréchal, L.; Perrin, S.; Dillmann, P.; Chaussé, A. Study of lepidocrocite $\gamma$-FeOOH electrochemical reduction in neutral and slightly alkaline solutions at $25^{\circ} \mathrm{C}$. Electrochim. Acta 2005, 51, 745-753. [CrossRef]

45. Liu, A.; Liu, J.; Pan, B.; Zhang, W.X. Formation of lepidocrocite $(\gamma-F e O O H)$ from oxidation of nanoscale zero-valent iron (nZVI) in oxygenated water. RSC Adv. 2014, 4, 57377-57382. [CrossRef]

46. Kassim, J.; Baird, T.; Fryer, J.R. Electron microscope studies of iron corrosion products in water at room temperature. Corros. Sci. 1982, 22, 147-158. [CrossRef]

47. Cavani, F.; Trifirò, F.; Vaccari, A. Hydrotalcite-type anionic clays: Preparation, properties and applications. Catal. Today 1991, 11, 173-301. [CrossRef]

48. Ingram, L.; Taylor, H.F.W. The crystal structures of sjögrenite and pyroaurite. Mineral. Mag. J. Mineral. Soc. 1967, 36, 465-479. [CrossRef]

49. Cao, Y.; Guo, Q.; Liang, M.; Sun, W. Sb(III) and $\mathrm{Sb}(\mathrm{V})$ removal from water by a hydroxyl-intercalated, mechanochemically synthesized Mg-Fe-LDH. Appl. Clay Sci. 2020, 196, 105766. [CrossRef]

50. Chen, J.; Feng, J.; Yan, L.; Li, H.; Xiong, C.; Ma, S. In situ growth process of Mg-Fe layered double hydroxide conversion film on MgCa alloy. J. Magnes. Alloy. 2020, 9, 1019-1027. [CrossRef]

51. Gong, C.; Bai, Y.J.; Qi, Y.X.; Lun, N.; Feng, J. Preparation of carbon-coated MgFe2O4 with excellent cycling and rate performance. Electrochim. Acta 2013, 90, 119-127. [CrossRef]

52. Leonés, A.; Lieblich, M.; Benavente, R.; Gonzalez, J.L. Potential Applications of Magnesium-Based Polymeric Nanocomposites Obtained by Electrospinning Technique. Nanomaterials 2020, 10, 1524. [CrossRef]

53. Israr, M.; Iqbal, J.; Arshad, A.; Gómez-Romero, P.; Benages, R. Multifunctional $\mathrm{MgFe}_{2} \mathrm{O}_{4} / \mathrm{GNPs}$ nanocomposite: Graphenepromoted visible light driven photocatalytic activity and electrochemical performance of $\mathrm{MgFe}_{2} \mathrm{O}_{4}$ nanoparticles. Solid State Sci. 2020, 110, 106363. [CrossRef]

54. Scarcello, E.; Lison, D. Are Fe-based stenting materials biocompatible? A critical review of in vitro and in vivo studies. J. Funct. Biomater. 2020, 11, 2. [CrossRef] [PubMed]

55. Turkin, A.I.; Drebushchak, V.A. Synthesis and calorimetric investigation of stoichiometric Fe-spinels: $\mathrm{MgFe}_{2} \mathrm{O}_{4}$. J. Cryst. Growth 2004, 265, 165-167. [CrossRef]

56. Ilhan, S.; Izotova, S.G.; Komlev, A.A. Synthesis and characterization of $\mathrm{MgFe}_{2} \mathrm{O}_{4}$ nanoparticles prepared by hydrothermal decomposition of co-precipitated magnesium and iron hydroxides. Ceram. Int. 2015, 41, 577-585. [CrossRef]

57. Chen, Q.; Rondinone, A.J.; Chakoumakos, B.C.; Zhang, Z.J. Synthesis of superparamagnetic $\mathrm{MgFe}_{2} \mathrm{O}_{4}$ nanoparticles by coprecipitation. J. Magn. Magn. Mater. 1999, 194, 1-7. [CrossRef]

58. Huang, Y.; Tang, Y.; Wang, J.; Chen, Q. Synthesis of $\mathrm{MgFe}_{2} \mathrm{O}_{4}$ nanocrystallites under mild conditions. Mater. Chem. Phys. 2006, 97, 394-397. [CrossRef]

59. Šepelák, V.; Bergmann, I.; Menzel, D.; Feldhoff, A.; Heitjans, P.; Litterst, F.J.; Becker, K.D. Magnetization enhancement in nanosized $\mathrm{MgFe}_{2} \mathrm{O}_{4}$ prepared by mechanosynthesis. J. Magn. Magn. Mater. 2007, 316, 764-767. [CrossRef]

60. Maensiri, S.; Sangmanee, M.; Wiengmoon, A. Magnesium ferrite $\left(\mathrm{MgFe}_{2} \mathrm{O}_{4}\right)$ nanostructures fabricated by electrospinning. Nanoscale Res. Lett. 2009, 4, 221-228. [CrossRef]

61. Verma, S.; Joy, P.A.; Khollam, Y.B.; Potdar, H.S.; Deshpande, S.B. Synthesis of nanosized $\mathrm{MgFe}_{2} \mathrm{O}_{4}$ powders by microwave hydrothermal method. Mater. Lett. 2004, 58, 1092-1095. [CrossRef]

62. Šepelák, V.; Schultze, D.; Krumeich, F.; Steinike, U.; Becker, K.D. Mechanically induced cation redistribution in magnesium ferrite and its thermal stability. Solid State Ion. 2001, 141-142, 677-682. [CrossRef]

63. Xu, Q.; Wei, Y.; Liu, Y.; Ji, X.; Yang, L.; Gu, M. Preparation of Mg/Fe spinel ferrite nanoparticles from Mg/Fe-LDH microcrystallites under mild conditions. Solid State Sci. 2009, 11, 472-478. [CrossRef]

64. Hansen, H.C.B.; Taylor, R.M. Formation of synthetic analogues of double metal-hydroxy carbonate minerals under controlled $\mathrm{pH}$ conditions: I. The synthesis of pyroaurite and reevesite. Clay Miner. 1990, 25, 161-179. [CrossRef]

65. Sikora-Jasinska, M.; Paternoster, C.; Mostaed, E.; Tolouei, R.; Casati, R.; Vedani, M.; Mantovani, D. Synthesis, mechanical properties and corrosion behavior of powder metallurgy processed $\mathrm{Fe} / \mathrm{Mg} 2 \mathrm{Si}$ composites for biodegradable implant applications. Mater. Sci. Eng. C 2017, 81, 511-521. [CrossRef]

66. Sikora-Jasinska, M.; Chevallier, P.; Turgeon, S.; Paternoster, C.; Mostaed, E.; Vedani, M.; Mantovani, D. Understanding the effect of the reinforcement addition on corrosion behavior of $\mathrm{Fe} / \mathrm{Mg} 2 \mathrm{Si}$ composites for biodegradable implant applications. Mater. Chem. Phys. 2019, 223, 771-778. [CrossRef] 